\title{
Determination of Element Concentrations in Commercial Infant Formulas Using Atomic Absorption Spectrometry
}

\author{
Songul Unuvar ${ }^{\mathrm{a}, *}$, Ebru Kuyumcu Savan $^{\mathrm{b}}$, and Nagihan M. Karaaslan ${ }^{\mathrm{c}}$ \\ a Inonu University, Faculty of Pharmacy, Department of Pharmaceutical Toxicology, 44280 Malatya, Turkey \\ b Inonu University, Faculty of Pharmacy, Department of Analytical Chemistry, 44280 Malatya, Turkey \\ c Munzur University, Faculty of Engineering, Department of Chemical Engineering, 62000 Tunceli, Turkey
}

\section{INTRODUCTION}

Nutrition is crucial to health and growth, particularly for infants and children (1). There are some options to breast milk which play an important role in the nutrition of infants but the World Health Organization (WHO) suggests breastfeeding as the best nutritional choice (2). The nutritional benefits of breastfeeding include protection against diseases (3-4). Nevertheless, in some cases breastfeeding has to be interrupted and the babies are fed with an infant formula or when the mothers cannot provide enough milk to meet their nutritional needs and they combine breast milk with an infant formula (5). Infant formulas are usually made from milkbased feeds; some are made from soybean which is suitable for those who are allergic to cow's milk (6). The most commonly used infant formulas contain purified cow's milk as a source of protein, with a mixture of vegetable oils as a fat source, lactose as a carbohydrate source, vitamin-mineral combinations and other ingredients depending on the manufacturer (7). In certain subpopulations, infants and small children may be at more risk when consuming contaminated foods (8). The tissue contaminant/ toxin level in newborns can rise to higher levels compared to adults because of their low body weight and high food consumption per $\mathrm{kg}$ of body weight (9). In order to determine the safety and quality of milk and dairy products, toxic

\footnotetext{
* Corresponding autbor.

E-mail: songul.unuvar@inonu.edu.tr

Tel: +904223410660

Fax: +90422341 1217
}

\begin{abstract}
The presence of heavy metals, inadequate minerals and elements in infant foods is of great concern. In this study, the heavy metals aluminum ( $\mathrm{Al}$ ) and lead $(\mathrm{Pb})$, essential elements such as iron (Fe) and zinc ( $\mathrm{Zn})$, and minerals such as calcium (Ca), potassium $(\mathrm{K})$, magnesium $(\mathrm{Mg})$, and sodium (Na) were determined by atomic absorption spectrometry (AAS) in five different brands of 20 infant formula samples obtained from pharmacies and supermarkets in Malatya, Turkey. The Joint FAO/ WHO Expert Committee on Food Additives (JECFA) has set the maximum concentration levels of heavy metals in infant formula and levels of provisional tolerable weekly intake (PTWI) of these metals by infants. The levels of $\mathrm{Al}$ and $\mathrm{Pb}$ in the analyzed samples were found to be under legal limits. The recommended daily intake (RDI) of the essential elements and minerals were found within normal and permissible ranges, showing that the formulas are safe for infants.
\end{abstract}

metal levels are important components. Symptoms of heavy metal toxicity include dizziness, nausea, vomiting, diarrhea, sleeping disorders, loss of appetite, reduced awareness and attention deficit conditions. Heavy metal toxicity is also associated with Alzheimer's disease, Parkinson's disease, autism, lupus, amyotrophic lateral sclerosis, cardiovascular disease, depressed growth, and can cause fertility problems, nervous and immune system disorders, miscarriage, and even lead to infant deaths (10). For heavy metals, any exposure is unde- sirable, but acceptable levels have been determined for most food supplies.

Trace elements and minerals are necessary for biological processes and play an important role for normal growth and development. The rate of growth in infancy and early childhood is very high and trace element requirements are more critical during these periods. In the developing countries, inadequate complementary foods are one of the major causes of malnutrition (11). Currently, adding vitamins and trace elements to the products is a common practice among manufacturers. Sometimes, these have been added in large quantities to the point that they have been found to be toxic, even though they are essential in smaller, physiological amounts (12). For example, zinc is important for growth and muscle development of an infant and plays an important role in cell division which is massive during infancy; thus it is intentionally added to infant formulas. If too much $\mathrm{Zn}$ is added, it causes toxicity (13). Therefore, keeping the level of the added elements under control is necessary (14). The WHO has made suggestions as to the RDI (recommended daily intake) of minerals for infants and specified maximum levels of concentrations of toxic metals in infant formulas and levels of PTWI (provisional tolerable weekly intake) (15). Since the first year of an infant's life is very important for the development of the nervous, reproductive, digestive, respiratory and immune systems, baby food composition and consumption patterns are extremely important (16). 
In the present study, the contamination levels of formulas used for infants from 0-12 months old are studied with regard to the heavy metals of $\mathrm{Pb}$ and $\mathrm{Al}$, the essential elements Fe and $\mathrm{Zn}$, and the minerals $\mathrm{Ca}, \mathrm{K}, \mathrm{Mg}$, and $\mathrm{Na}$.

\section{EXPERIMENTAL}

\section{Instrumentation}

Analysis was carried out using a PerkinElmer ${ }^{\circledR}$ AAnalyst ${ }^{\mathrm{TM}} 800$ flame atomic absorption spectrometer (FAAS), equipped with THGA ${ }^{\circledR}$ graphite furnace, and Zeemaneffect background corrector (PerkinElmer, Inc., Shelton, CT, USA). Flame measurements were performed with a single slot burner head $(10 \mathrm{~cm}$ for air-acetylene flame, $5 \mathrm{~cm}$ for nitrous oxide flame) and a lamp. Al, Ca, Fe, K, Mg, Na, and Zn were determined with FAAS and the instrument operational parameters are listed in Table I. The determination of $\mathrm{Pb}$ was performed by graphite furnace atomic absorption spectrometer (GFAAS) and pyrolytically coated graphite tubes (PerkinElmer part no. B3 000641) with a platform and argon was used as the inert gas. The samples were injected into the graphite furnace using a Perkin-Elmer AS-91 autosampler (Table I). For the sample pretreatment a Milestone Start D closed vessel microwave system, operated at the maximum exit power of $1000 \mathrm{~W}$ was employed (Milestone Start S Microwave Labstation for Synthesis, Milestone Inc., USA). The samples were introduced inside high pressure vessels of 100-mL inner volume and nine samples were treated simultaneously. Teflon ${ }^{\circledR}$ reaction vessels were used for all digestion procedures. The reaction vessels were cleaned using $5 \mathrm{~mL}$ of concentrated nitric acid before each digestion.

\section{Reagents and Standard Solutions}

All chemicals were of analytical reagent grade. For the preparation of all solutions, double distilled water using a Milli-Q ${ }^{\circledR}$ system (18.2 $\mu \Omega \mathrm{cm}^{-1}$ resistivity, Millipore Corporation, USA) was used for all experiments. Suprapur ${ }^{\circledR} \mathrm{HNO}_{3}$ and $\mathrm{H}_{2} \mathrm{O}_{2}$ (E. Merck, Germany) were used. The element standard solutions were prepared by diluting a stock solution of $1000 \mathrm{mg} \mathrm{L}^{-1} \mathrm{Al}, \mathrm{Ca}, \mathrm{Fe}$, $\mathrm{K}, \mathrm{Mg}, \mathrm{Na}, \mathrm{Pb}$, and $\mathrm{Zn} . \mathrm{Mg}\left(\mathrm{NO}_{3}\right)_{2}$ and

TABLE I

Instrumental Operating Conditions for FAAS and GFAAS

\begin{tabular}{|c|c|c|c|c|c|c|c|}
\hline $\begin{array}{l}\text { FAAS } \\
\text { Element }\end{array}$ & $\begin{array}{l}\text { Acetylene } \\
\text { (L/min) }\end{array}$ & $\begin{array}{r}\mathrm{Ai} \\
(\mathrm{L} / \mathrm{n} \\
\end{array}$ & in) & $\begin{array}{l}\text { Wavelength } \\
(\mathrm{nm})\end{array}$ & $\begin{array}{r}\text { Slit V } \\
\text { (n }\end{array}$ & idth & $\begin{array}{l}\text { Measurement } \\
\text { Time } \\
\text { (sec) }\end{array}$ \\
\hline Al & 2.0 & 17 & & 309.3 & & & 3 \\
\hline $\mathrm{Ca}$ & 2.0 & 17 & & 422.7 & & & 3 \\
\hline $\mathrm{Fe}$ & 2.0 & 17 & & 248.3 & & & 3 \\
\hline $\mathrm{K}$ & 2.0 & 17 & & 766.5 & & 2 & 3 \\
\hline $\mathrm{Mg}$ & 2.0 & 17. & & 285.2 & & 7 & 3 \\
\hline $\mathrm{Na}$ & 2.0 & 17. & & 589.0 & & 2 & 3 \\
\hline $\mathrm{Zn}$ & 2.0 & 17. & & 213.9 & & & 3 \\
\hline $\begin{array}{l}\text { GFAAS } \\
\text { Element }\end{array}$ & $\begin{array}{l}\text { Sample } \\
\text { Volume } \\
(\mu \mathrm{L}) \quad(\end{array}$ & $\begin{array}{l}\text { Modifier } \\
(\mu \mathrm{L})\end{array}$ & $\begin{array}{l}\text { Wave- } \\
\text { length } \\
(\mathrm{nm})\end{array}$ & $\begin{array}{l}\underset{\text { Slit }}{\text { Width }} \\
\text { (nm) }\end{array}$ & $\begin{array}{c}\text { Pyrolysis } \\
\text { Temp. } \\
\left({ }^{\circ} \mathrm{C}\right)\end{array}$ & $\begin{array}{c}\text { Atomi- } \\
\text { zation } \\
\text { Temp. } \\
\left({ }^{\circ} \mathrm{C}\right)\end{array}$ & $\begin{array}{l}\text { Measure- } \\
\text { ment } \\
\text { Time } \\
\text { (sec) }\end{array}$ \\
\hline $\mathrm{Pb}$ & 10 & 3 & 283.3 & 0.7 & 1900 & 2450 & 3 \\
\hline
\end{tabular}




\section{Statistical Analysis}

The minimum, maximum, mean, and standard deviations of the data were subjected to statistical analysis using Microsoft ${ }^{\circledR}$ Office EXCEL ${ }^{\circledR}$ software (version 2007, Microsoft Corporation, USA).

\section{RESULTS AND DISCUSSION}

The limits of detection (LOD) and limits of quantification (LOQ) were calculated from the expressions $\mathrm{LOD}=3 \mathrm{SD} / \mathrm{b}$ and $\mathrm{LOQ}=$ $10 \mathrm{SD} / \mathrm{b}$, where SD is the standard deviation of the blank and $b$ is the slope of the analytical curve. As can be seen from Table II, the limits of detection values of the AAS are adequate for the determination of the trace elements in the infant formulas. The repeatability was calculated as the relative standard deviation (RSD\%). The precision of the results was satisfactory resulting in relative standard deviations varying from $0.48 \%$ to $1.17 \%$.

The average concentrations of $\mathrm{Al}, \mathrm{Ca}, \mathrm{Fe}, \mathrm{K}, \mathrm{Mg}, \mathrm{Na}, \mathrm{Pb}$, and $\mathrm{Zn}$ in infant formulas were determined with FAAS and GFAAS as shown in Table III. The average heavy metal contents in an infant formula for a

TABLE II

Detection Limits $\left(\mu \mathrm{g} \mathrm{g}^{-1}\right)$, $\left(\mathbf{N}^{\mathrm{a}}=\mathbf{1 0}\right)$

\begin{tabular}{cccl}
\hline $\begin{array}{l}\text { Ele- } \\
\text { ment }\end{array}$ & RSD $^{\mathrm{b}}(\%)$ & LOD & LOQ \\
\hline $\mathrm{Al}$ & 0.77 & 1.90 & 6.35 \\
$\mathrm{Ca}$ & 0.84 & 0.79 & 2.64 \\
$\mathrm{Fe}$ & 0.61 & 0.33 & 1.12 \\
$\mathrm{~K}$ & 0.6 & 0.81 & 2.7 \\
$\mathrm{Mg}$ & 0.67 & 0.07 & 0.24 \\
$\mathrm{Na}$ & 0.57 & 0.06 & 0.18 \\
$\mathrm{~Pb}$ & 0.48 & 0.01 & 0.02 \\
$\mathrm{Zn}$ & 0.63 & 0.16 & 0.53
\end{tabular}

${ }^{a}$ Number of determinations.

b The relative standard deviations were calculated as percentage corresponding to (s/x mean)*100 for blank samples.
0-6 months old and a 7-12 months old were found at $1.29 \pm 0.66 \mu \mathrm{g} \mathrm{g}^{-1}$ for $\mathrm{Al}, 0.16 \pm 0.02 \mu \mathrm{g} \mathrm{g-}{ }^{1}$ for $\mathrm{Pb}$, and $1.54 \pm 0.35 \mu \mathrm{g} \mathrm{g}^{-1}$ for $\mathrm{Al}$, and $0.18 \pm 0.08 \mu \mathrm{g} \mathrm{g}^{-1}$ for $\mathrm{Pb}$, respectively. The average essential element contents in an infant formula for a 0-6 months old infant and a 7-12 months old infant were found at $61.34 \pm 13.72 \mu \mathrm{g} \mathrm{g}^{-1}$ for $\mathrm{Fe}$, $29.72 \pm 4.04 \mu \mathrm{g} \mathrm{g}^{-1}$ for $\mathrm{Zn}, 72.6 \pm 4.05$ $\mu \mathrm{g} \mathrm{g}^{-1}$ for $\mathrm{Fe}$, and $34.64 \pm 6.32 \mu \mathrm{g} \mathrm{g}^{-1}$ for $\mathrm{Zn}$, respectively. The average mineral contents in a 0-6 month infant formula were found at $4.19 \pm 0.45 \mathrm{mg} \mathrm{g}^{-1}$ for $\mathrm{Ca}, 6.53 \pm 1.09$ $\mathrm{mg} \mathrm{g}^{-1}$ for $\mathrm{K}, 0.51 \pm 0.08 \mathrm{mg} \mathrm{g}^{-1}$ for $\mathrm{Mg}, 0.95 \pm 0.19 \mathrm{mg} \mathrm{g}^{-1}$ for $\mathrm{Na}$, and for a 7-12 month infant formula were $4.35 \pm 0.96 \mathrm{mg} \mathrm{g}^{-1}$ for $\mathrm{Ca}$, $6.08 \pm 2.27 \mathrm{mg} \mathrm{g}^{-1}$ for $\mathrm{K}, 0.50 \pm 0.15$ $\mathrm{mg} \mathrm{g}^{-1}$ for $\mathrm{Mg}$, and $1.89 \pm 0.75 \mathrm{mg} \mathrm{g}^{-1}$ for $\mathrm{Na}$, respectively. None of the samples contained aluminum or lead in amounts that could repre-

\section{TABLE III Heavy and Essential Element Concentrations in Infant Formula Samples Determined by AAS}

(Mean \pm Standard deviation, average of three repeated measurements)

\begin{tabular}{|c|c|c|}
\hline Element & $\begin{array}{l}\text { 0-6 months } \\
(\mathrm{n}: 10)\end{array}$ & $\begin{array}{c}\text { 7-12 months } \\
\text { (n: } 10)\end{array}$ \\
\hline $\begin{array}{l}\mathrm{Al} \\
\left(\mu \mathrm{g} \mathrm{g^{-1 }}\right)\end{array}$ & $1.29 \pm 0.66$ & $1.54 \pm 0.35$ \\
\hline $\begin{array}{l}\mathrm{Ca} \\
\left(\mathrm{mg} \mathrm{g}^{-1}\right)\end{array}$ & $4.19 \pm 0.45$ & $4.35 \pm 0.96$ \\
\hline 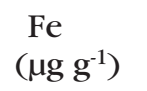 & $61.34 \pm 13.72$ & $72.6 \pm 4.05$ \\
\hline $\begin{array}{l}\mathrm{K} \\
\left(\mathrm{mg} \mathrm{g} \mathrm{g}^{-1}\right)\end{array}$ & $6.53 \pm 1.09$ & $6.08 \pm 2.27$ \\
\hline $\begin{array}{l}\mathrm{Mg} \\
\left(\mathrm{mg} \mathrm{g}^{-1}\right)\end{array}$ & $0.51 \pm 0.08$ & $0.50 \pm 0.15$ \\
\hline $\begin{array}{l}\mathrm{Na} \\
\left(\mathrm{mg} \mathrm{g}^{-1}\right)\end{array}$ & $0.95 \pm 0.19$ & $1.89 \pm 0.75$ \\
\hline 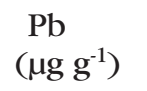 & $0.16 \pm 0.02$ & $0.18 \pm 0.08$ \\
\hline $\begin{array}{l}\mathrm{Zn} \\
\left(\mu \mathrm{g} \mathrm{g} \mathrm{g}^{-1}\right)\end{array}$ & $29.72 \pm 4.04$ & $34.64 \pm 6.32$ \\
\hline
\end{tabular}

$\mathrm{n}=10$, different samples. sent a health hazard for infants. All concentrations of essential elements and minerals were found within the recommended values.

The accuracy of the results was verified by analyzing the concentration of $\mathrm{Al}, \mathrm{Ca}, \mathrm{Fe}, \mathrm{K}, \mathrm{Mg}, \mathrm{Na}, \mathrm{Pb}$, and $\mathrm{Zn}$ in NIST-SRM 8418 Wheat Gluten. The certified and observed values for the NIST-SRM 8418 Wheat Gluten are presented in Table IV. The results of the analyzed metals were generally in agreement with the NIST certified values. The obtained recoveries of the standard reference material NIST-SRM 8418 Wheat Gluten were $92 \%$ for $\mathrm{Al}, \mathbf{8 7 \%}$ for $\mathrm{Ca}, 93 \%$ for $\mathrm{Fe}$, $89 \%$ for $\mathrm{K}, 97 \%$ for $\mathrm{Mg}, 96 \%$ for $\mathrm{Na}$, $90 \%$ for $\mathrm{Pb}$, and $91 \%$ for $\mathrm{Zn}$.

The mean daily intake of the elements was calculated based on the estimated average amount of infant formulae $\left(\mathrm{g} \mathrm{day}^{-1}\right)$. The recommended daily intake (RDI) is the average daily dietary intake level that is sufficient to meet the nutrient requirements of nearly all (97 to 98\%) individuals in a life stage and gender group (18). The daily intake of $\mathrm{Al}, \mathrm{Ca}, \mathrm{Fe}, \mathrm{K}, \mathrm{Mg}, \mathrm{Na}, \mathrm{Pb}$, and $\mathrm{Zn}$ was analyzed and calculated and the results are listed in Table V.

\section{TABLE IV}

Results for NIST-SRM 8418 Wheat Gluten

(Mean \pm Standard Deviation, average of three repeated measurements)

\begin{tabular}{llll}
\hline $\begin{array}{c}\text { Ele- } \\
\text { ments }\end{array}$ & $\begin{array}{c}\text { Certi- } \\
\text { fied } \\
\left(\mu \mathrm{g} \mathrm{g}^{-1}\right)\end{array}$ & $\begin{array}{c}\text { Mea- } \\
\text { sured } \\
\left(\mu \mathrm{g} \mathrm{g}^{-1}\right)\end{array}$ & $\begin{array}{c}\text { Recov- } \\
\text { ery } \\
(\%)\end{array}$ \\
\hline $\mathrm{Al}$ & 10.8 & $9.9 \pm 0.48$ & 92 \\
$\mathrm{Ca}$ & 369 & $321 \pm 52$ & 87 \\
$\mathrm{Fe}$ & 54.3 & $50.5 \pm 6.4$ & 93 \\
$\mathrm{~K}$ & 472 & $420 \pm 61$ & 89 \\
$\mathrm{Mg}$ & 510 & $493 \pm 38$ & 97 \\
$\mathrm{Na}$ & 0.142 & $0.136 \pm 0.06$ & 96 \\
$\mathrm{~Pb}$ & 0.10 & $0.09 \pm 0.01$ & 90 \\
$\mathrm{Zn}$ & 53.8 & $48.8 \pm 5.4$ & 91 \\
\hline
\end{tabular}


The recommended daily intake and the provisional tolerable weekly intake were calculated according to a feeding table for normal healthy babies and are listed in Tables VI and VII, respectively. The related results are presented in Table $\mathrm{V}$ and compared with the daily intake values recommended by WHO (15). Daily consumed powder formula values were obtained from feeding tables and the reference mean body weights were used (18). The percentages of daily intake of minerals are presented in Table VI and compared to the recommended daily intake as suggested by WHO (15).

\section{Ca in Infant Formula}

In the first year of life, human milk and infant formulas are the main sources of $\mathrm{Ca}$. Even a very low Ca intake may contribute to the development of rickets in infants and children. Maintenance of adequate $\mathrm{Ca}$ intake during childhood is essential for the development of maximal peak bone mass. Increasing peak bone mass can be an important way to reduce the risk of osteoporosis in adulthood (19).

\section{Fe in Infant Formula}

Fe deficiency-anemia is widely observed in premature infants and between 6 months to 2 years of age (20). Formulas without supplemental Fe have been shown to cause iron deficiency after 4 months of life. Therefore, formulas should be supplemented with Fe (21). On the other hand, Fe causes tissue damage and some other diseases in humans at high concentrations (22).

\section{$K$ in Infant Formula}

$\mathrm{K}$ is a necessary mineral and an electrolyte for cardiac and tissue health, skeletal contraction and gastrointestinal function (23).

\section{Mg in Infant Formula}

$\mathrm{Mg}$ is widely distributed in nature and deficiency of this mineral is rare (24).

\section{Atomic Apectroscopy 1 Vol. 38(4), July/August 2017}

\section{$\mathrm{Na}$ in Infant Formula}

$\mathrm{Na}$ intake should vigilantly be monitored in infants since their excretory system eliminates sodium with less efficiency than in adults. Accordingly, high amounts of $\mathrm{Na}$ can cause immediate health implications for the young infants, besides affecting their long-term health status (23).

\section{Zn in Infant Formula}

Intake of high or low amounts of $\mathrm{Zn}$ can affect the health of an infant. Zn deficiency in children is characterized mainly by dermatitis and alopecia during infancy and by short stature during childhood (20).

The concentration of essential elements in the present study was therefore similar to those found in Norway (11). Zand et al. (2011) experimentally determined the values of minerals and trace elements in infant foods (except for potassium) and found that they were higher than the declared values by WHO (25).

TABLE V

Calculation of Daily Intake of Determinated Elements in Infant Formulas

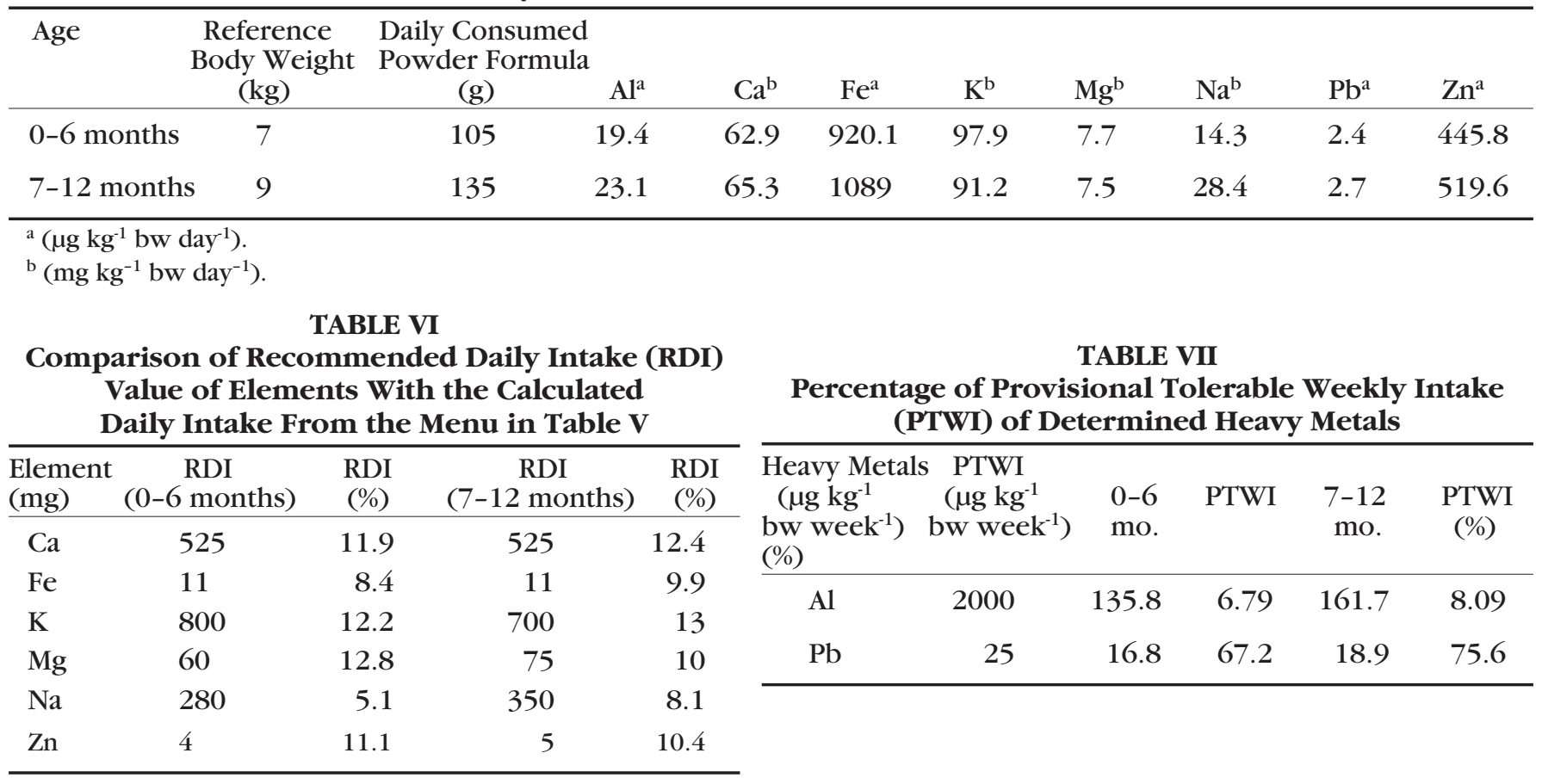




\section{$\mathrm{Pb}$ and $\mathrm{Al}$ in Infant Formula}

Table VII shows the weekly $\mathrm{Pb}$ and $\mathrm{Al}$ intake and (\%) of provisional tolerable weekly intake (PTWI) calculated according to Table V. Aluminum is not considered to be an essential element for infants but excessive amounts cause an increased deposition of $\mathrm{Al}$ in the bone and in the central nervous system, thus causing reduced renal function in infants and children. In addition, increased amounts of dietary $\mathrm{Al}$ may contribute to decreased skeletal mineralization $(26,27)$. Aluminum compounds are used as food additives in foods in some countries (28). Many of the formulas were packaged using aluminum-based materials. The content of Al both in ready-to-drink milks and milk powders has been reported by Chuchu et al. (2013) to be higher than permissible limits (29). The mean values for $\mathrm{Al}$ in formulas of the present study do not exceed the JECFA (Joint Expert Committee for Food Additives) established PTWI of $2000 \mu \mathrm{g} / \mathrm{kg}$ bw/week (30) and are similar to those found in a Canadian study (31). Therefore, the control of $\mathrm{Al}$ in infant formulas seems to be essential. Infants and young children may absorb as much as 50\% of dietary $\mathrm{Pb}$, compared to only $10 \%$ for adults (32). As a result of its natural presence in the environment, $\mathrm{Pb}$ also occurs naturally at low levels in the food chain and in commercial food products. While $\mathrm{Pb}$ can be harmful to the health of people of all ages, infants and children are a susceptible subpopulation for $\mathrm{Pb}$ exposure. This age group is particularly at risk of the neurodevelopmental effects of $\mathrm{Pb}$ exposure, resulting in the reduction of the Intelligence Quotient (IQ) score and attention-related behaviors (attention-deficit hyperactivity disorder) (33). In addition, high levels of $\mathrm{Pb}$ in the body cause anemia, colic, headache, brain damage, and central nervous system disorder (22). The FAO/WHO

JECFA set the PTWI for lead at 25 $\mu \mathrm{gg}^{-1} \mathrm{bw} / \mathrm{week}^{-1}$ for infants $(34$, 35). Thus regular monitoring of heavy metals such as lead in infant foods is most important (32).

The most ideal way of feeding babies is breastfeeding. As well as protecting babies against infection, breastfeeding prevents the progress of allergic diseases (9). However, WHO reports that only $38 \%$ of infants receive breast milk in their first 6 months worldwide (15). From the results of some studies, it is evident that the infant formula samples were contaminated with variable amounts of heavy metals (4, 6, 8-10, 12-14, 29, 31, 32, 36). The effect of metal poisoning in infants is compounded by the fact that even at low levels of exposure, metals bio-accumulate in the vital organs such as the kidneys, an effect that persists in adulthood (36). Due to the bioaccumulation of metals, the presence of toxic metals in infant foods is of great concern and therefore, infant formula products need regular monitoring to ascertain infant safety. In this study, it was found that the minerals determined in the studied infant formula samples do not fall below the recommended daily intake and the toxic metal levels were within the acceptable/standard limits and were not observed to cause any significant toxicity.

\section{CONCLUSION}

In the present study, the contents of heavy metals, essential elements and minerals (Al, Ca, Fe, Mg, $\mathrm{Na}, \mathrm{K}, \mathrm{Pb}$, and $\mathrm{Zn}$ ) in different infant formulas were investigated. For this aim, 20 infant formulas from five different manufacturers were collected from pharmacies and supermarkets in Malatya, Turkey and analyzed by atomic absorption spectrometry. The obtained results showed that none of the samples contained $\mathrm{Al}$ or $\mathrm{Pb}$ in amounts that could represent a health hazard for infants. In addition, all concentrations of the essential elements and minerals were also found within the recommended FAO/WHO values. This study demonstrated that continued investigation about the element composition in infant formulas is essential and needed.

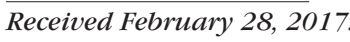

\section{REFERENCES}

1. J. Cross, Newborn and Infant Nursing Reviews 15,128 (2015).

2. WHO, Strengthening action to improve feeding of infants and young children 6-23 months of age in nutrition and child health programmer. Geneva, Switzerland, (6-9 Oct. 2008).

3. W.H. Oddy, Breastfeeding Rev. J. 9 , 8 (2001).

4. O.R. Johnson and O.O. Samson, Scholars Academ. J. Biosci. 1, 318 (2013).

5. C. Sabater, M. Prodanov, A. Olano, N. Corzo and A. Montilla, Food Chem. 194, 6 (2016).

6. S.A.M. Burrell and C. Exley, BMC Pediatric. 10, 63 (2010).

7. A. Ryan, Pediatric. 99, 12 (1997).

8. G.R.J. Khaniki, Int. J. Dairy Tech. 2, 104 (2007).

9. A. Oskarsson, I. Palminger and J.P.K. Sundberg, Analyst 123, 19 (1998).

10. S.F.A. Abd-El Aal, J. Americ. Sci. 8, 665 (2012).

11. R. Melo, K. Gellein, L., Evje and T. Syversen, Food Chem. Toxicol. 46, 3339 (2008).

12. G. Lutfullah, A.A. Khan, A.Y. Amjad and S. Perveen, Sci. World J. 1 (2014).

13. V.O. Odhiambo, MSc Thesis, Kenyatta University, Nairobi, Kenya (2014).

14. F.A.A.E. Salah, I.A. Esmat and A.B Mohamed, Int. Food Res. J. 20, 1807 (2013).

15. WHO, Complementary feeding. 


\section{Atomic}

Infant and Young Child Feeding: Model Chapter for Textbooks for Medical Students and Allied Health Professionals, 7,19 (2009).

16. M. Pandelova, W.L. Lopez, B. Michalke and K.W. Schramm, J. Food Comp. Anal. 27, 120 (2012).

17. P.Vim, D.L. Massart, and J. SmeyersVerbeke, Fresenius J. Anal. Chem. 343, 526 (1992).

18. Food and Nutrition Board, Institute Of Medicine. Dietary Reference Intakes for Calcium, Phosphorus, Magnesium, Vitamin D, and Fluoride. Washington, DC: The National Academies Press (USA). (1997).

19. S.S. Baker, W.J. Cochran, C.A. Flores, M.K Georgieff, M.S Jacobson, T. Jaksic and N.F. Krebs, Pediatrics 104, 1152 (1999).

20. H. Kodama, Japan Medic. Assoc. 47, 376 (2004).

21. B. Lonnerdal, J. Nut. 119, 1839 (1989)

22. A. Shah, A. Niaz, N. Ullah, A. Rehman, M. Akhlaq, M. Zakir and M.S. Khan, , J. of Chem. 1 (2013).

23. A. Waseem, M. Nafees, G. Murtaza, A. Sajjad, Z. Mehmood, and A.R. Siddiqi, Iran. J. Public Health 43 1204 (2014).

24. Committee on the Evaluation of the Addition of Ingredients New to Infant. Comparing Infant Formulas with Human Milk, Washington, D.C.: National Academies Press (USA), (2004).

25. N. Zand, B.Z. Chowdhry, F.B. Zotor, D.S. Wray, P. Amuna and F.S. Pullen, Food Chem. 128, 123 (2011).

26. F.R. De Amorim, C. Bof, M.B Franco, J.B.B. Da Silva and C.C. Nascentes, Microchem. J.82, 168 (2006).

27. J. Bhatia and F. Greer, Pediatric. 12, 1062 (2008)

28. M.G. Soni, S.M. White, W.G. Flamm and G.A. Burdock, Regul. Toxic. Pharm. 33, 66 (2001)

29. N. Chuchu, B. Patel, B. Sebastian and C. Exley, BMC Pediatric. 13, 162 (2013).

30. J.E.C.F.A. Seventy-fourth Meeting of the Joint FAO/WHO Expert Committee on Food Additives (2011).

31. R. Dabeka, A. Fouquet, S. Belisle and S. Turcotte, Food Add. \& Contam., Part A, Chem. Anal. Cont. Exposure \& Risk Assess. 28, 744 (2011).

32. L.M. Hafez and A.M. Kishk, The J. Egyp. Pub. Health Assoc. 83, 3 (2008).

33. Environment Canada, Health Canada. Risk Management Strategy for Canada (2010).

34. FAO/WHO, Evaluation of certain food additives and contaminants. Fifty-seventh report of the Joint FAO/WHO Expert Committee on Food Additives, Vol. 909 (2002).

35. FAO/WHO, Evaluation of certain food additives. Seventy-first report of the Joint FAO/WHO Expert Committee on Food Additives, Vol. 956 (2010).

36. V.O. Odhiambo, R. Wanjau, J.O. Odundo and M.P. Nawiri, Afr. J. Food Sci. 9, 437 (2015). 